\title{
DNA Replication Licensing Factor MCM3
}

National Cancer Institute

\section{Source}

National Cancer Institute. DNA Replication Licensing Factor MCM3. NCI Thesaurus. Code C28684.

DNA replication licensing factor MCM3 (808aa, $~ 91 \mathrm{kDa})$ is encoded by the human MCM3 gene. This protein is involved in the modulation of the cell cycle. 